Society for the Anthropology of Work • Policing and Labor

\title{
Digital Hailing: Social Media and Police Work
}

Hayal Akarsu

Published on: Dec 01, 2020

DOI: 10.21428/1d6be30e.27969821

License: Creative Commons Attribution 4.0 International License (CC-BY 4.0). 
Digital tools and technologies, from biometric systems to big data analytics, have dramatically changed practices and sites of policing and state surveillance in the last decade. Mapping risks onto bodies and spaces, these technologies play an essential role in fields such as border management, crime investigation, disaster prevention, and counterterrorism. The promotion of digital technology in police work relies on techno-optimistic promises about the capacity of these tools and platforms to reduce police violence and to make police more efficient and effective. Yet the integration of digital technologies into policing has created complex cultural forms, simultanously utopian and dystopic, such as the flying motorbikes of police in Dubai or the face recognition-integrated sunglasses of cops in China.

In the Turkish context, where I conducted ethnographic research on police reforms between 2015 and 2017, some of these emerging policing technologies have been introduced by European Union-supported projects to increase the technical capacity of the police. These projects have sought to equip the Turkish National Police with new evidence-gathering and knowledge-making technologies-the ultimate aim of which was to make police work more professional and scientific. A concomitant proliferation of both private security companies and high-tech security industries in Turkey also contributed to the national police's rapid and profound integration of digital technologies, as I observed at international security technology fairs that I attended in Istanbul and Ankara.

These technologies transform how state authorities and the police (as a crucial node in a broader security/knowledge system) classify, govern, and organize bodies and spaces in both virtual and material worlds. In their wake, the future of policing seems to be powered by analytics and algorithms. But what are the effects of new digital tools and communication mediums on police work-particularly on not-so-visible, mundane practices? How do the police, for instance, capitalize on social media, an everyday communication tool for many? By looking at changing forms of protest (and political) policing in Turkey, this essay discusses how the police's digital hailing-both in digital spaces and with digital tools-has subjected people, especially political dissidents, to a new regime of state surveillance. Digital police work and what constitutes the digital rights of citizens have become emerging sites of debate around human rights and policing in contemporary Turkey. 
In early 2016, the Ankara branch of Turkey's Human Rights Association held a small sit-in in front of the human rights monument on Yüksel Avenue to read a statement against ongoing human rights violations committed by the state in the country's Kurdish-majority cities. I accompanied a team of six police officers from Ankara's Public Order unit-a unit of the Directorate of Security that oversees riot police-as they gathered to police this unauthorized political protest. The protesters had not notified the authorities that they planned to hold a gathering, which was required by law.

I met with the officers on the patio of a nearby café, overlooking the monument. We drank several cups of tea and smoked cigarettes, chatting mostly about police officers' poor working conditions (long hours, not enough holidays, and so on), and they halfjokingly asked me questions about job opportunities for them in the United States. For almost two hours, only one of them left the café to check on the sit-in. Police in Turkey are usually impatient with such unauthorized gatherings (especially those held by proKurdish and leftist groups), often dispersing them with tear gas, water cannons, and other violent techniques. I was surprised to observe their indifference this time. But their reasoning was clear. There were two other police officers in the demonstration area who were videorecording the protest, minute by minute, from different angles. One of the group boasted about the face recognition software they would use when analyzing the video afterward. Another one joked: "There is no use for us [police] anymore on the street." They had learned the location and time of the sit-in by following what they termed "known protesters" on Twitter. Instead of disrupting the sitin, they saw it as an excuse to profile those who had attended the protests. Erdem, a social media analyst for the unit, said that he felt refreshed by coming over to Yüksel Avenue for a protest. Tired of sitting at a desk in a gloomy office and browsing political dissidents' social media accounts every day, it was refreshing to hang out with his fellow officers in an open-air café.

Police stalk citizens on social media, gathering what they call "open source intelligence." Rather than hiding in secret corners, they do hashtag research on political dissidents, compiling intelligence from publicly available sources such as the updates that citizens share on their personal websites and social media profiles. The Public Order unit does not even have high-skilled data scientists like the ones who work in the Department of Cyber Crime, the director of which boasted in an interview 
published in 2018 that "we [Turkey] rank number one in the world in the amount of digital material we analyze every year."

Portraying the officers in the Cyber Crime unit as the "super kids of the police" (emniyetin süper çocukları), this interview also underlined the importance of "crowdsourced intelligence," that is, the reports submitted to the police by ordinary citizens (see Akarsu 2020). Indeed, since the Gezi Park protests in 2013, police have been tracking hacktivists, hashtag protesters, cell phone journalists, and anonymous whistleblowers online. Along the way, the government hired an army of online trolls to manipulate public opinion and put pressure on government critics. However, with the remilitarization of the Kurdish conflict in 2015 and the failed coup attempt in 2016, the crackdown on political opposition has intensified to an unprecedented degree, resulting in broader surveillance of digital spaces in the name of security and terrorism-prevention measures.

\section{Visit the web version of this article to view interactive content.}

A month after the coup attempt, for instance, the Turkish National Police introduced the Directorate of Security's Mobile Informing App on Twitter: "You can use the Directorate of Security's Android and IOS apps for your \#ihbar [report on someone or something]." Another tweet called for "cyber patrols," asking ordinary citizens to take a screenshot of any terrorist activity online and to file a complaint. Police officers who I knew from my fieldwork in fact complained about how their online portal went down in the months following the failed coup attempt due to an unexpected influx of crowdsourced data. Two years later, in 2018, the government bragged about "its 'cyber army' of 2,700, keeping an eye on the online activities of 45 million users." As a consequence, numerous people have been detained or jailed just because of their antigovernment comments on social media. Others have faced criminal investigation because of social media posts deemed critical to government actions like Turkey's military interventions in Syria, or for reporting_COVID-19 cases that the government has tended to undercount.

Maintaining a proper digital footprint was also a major concern for residents of the neighborhood where I conducted research. Some, for instance, attended the Democracy and Martyrs' Rally (organized by President Erdoğan in August 2016 to celebrate the foiling of the coup attempt) in order to take selfies to be shared on their social media accounts. Selfies were part of an evidentiary regime of showing your 
support for the government and geomarking your presence among loyal people. This was a common way of cultivating a social media persona, especially for those who wanted to avoid the digital attention of state and security services for political or personal reasons (such as not being dismissed from their civil service jobs). Some also wanted to attract digital attention in order to receive certain political and economic benefits. Selfies were a way to register a particular loyalty to the government. Through selfies shared on social media, some Turkish citizens also evidenced their willingness to participate in policing in the midst of political polarization and a massive crackdown on any opposition.

The governing Justice and Development Party's controversial Social Media Law, which entered into force in 2020, has intensified debates over digital state surveillance in Turkey. The law requires social media companies to store users' data and to make them available for government use when needed for "security reasons," broadly defined. It also imposes harsh penalties and sanctions if companies do not comply with requests to remove contentious content. Indeed, the Turkish government had already been in contact with various Internet providers and media and tech companies to monitor dissident activity online, as my interlocutors told me in 2016. Contestations among corporate actors and the government over who owns this trace data (corporations, users, or the state) and public discussions around whether or not social media is a right bring up new questions around data sovereignty-an emerging trope of human rights and policing debates in Turkey.

Police officers who I met in the field had mixed responses to this transformation. Some of them were pleased with the expansion of their reach into citizens' digital lives. Others felt that their work had become of secondary importance, with their expertise replaced by that of tech-savvy officers; still others felt overwhelmed with the additional work that digital policing has imposed on top of their already heavy workload. In any case, the surveillance and datafication of people's (digital) lives has dramatically changed traditional police work, even for officers not directly affiliated with cybercrime units such as the Public Order team I accompanied in the field. Yet their experience also showed how the digitalization of policework went hand in hand with what we might call analog policing techniques and ideologies. These new digital technologies of policing have ended up targeting the political opposition, as well as racialized, gendered, and classed others-groups that are (not for the first time) disproportionately subjected to the scrutiny of the police. ${ }^{1}$ Exploring such continuities between analog and digital forms of policing and security ideologies is important not just to analyze the changing nature of police work, but also to unsettle techno- 
optimistic and epochal formulations sometimes attached to the digitalization of politics and selves.

Then, too, the digitalization of police work raises important practical and ethical questions for ethnographic fieldwork-especially in the time of COVID-19, when many anthropologists are looking for ways to integrate digital tools into their research designs. For instance, how are we going to avoid the unwarranted attention of security and police forces while conducting remote research? How are we going to manage the digital footprints of our research projects, especially in regions like the Middle East that are central to various security and military interests? Given my discussion of police reliance on "open source intelligence," such questions require not just the development of contingency plans for ongoing research but also a rethinking of the future of anthropological work in digitally mediated (police) worlds.

\section{Note}

1. Of course, digital platforms and technologies have also given way to new forms of politics and protests, as evidenced by a range of protest movements from the Arab Spring to Black Lives Matter. Digital tools do not only serve as mediums of communication, but have also been turned into new sites of counterhegemonic struggles (e.g., Coleman 2014; Postill 2018).

\section{Author Bio}

Hayal Akarsu is Junior Research Fellow at the Crown Center for Middle East Studies and Lecturer in Anthropology at Brandeis University. Her recent research project, an ethnography of police reforms in Turkey, has yielded publications in American Ethnologist, Anthropology Today, and Society and Space. Her book manuscript, Force Experts: Afterlives of Police Reforms in Turkey, explores the connections between policing, human rights, transnational flows and governance, and lived experiences of security and insecurity.

\section{Preview Image}

Photo by $\underline{\text { Chris Henry. }}$

\section{References}

Akarsu, Hayal. 2020. “Citizen Forces: The Politics of Community_Policing in Turkey..” American Ethnologist 47(1): 27-42. 
Coleman, Gabriella. 2014. Hacker, Hoaxer, Whistleblower, Spy: The Many Faces of Anonymous. New York: Verso.

Postill, John. 2018. The Rise of Nerd Politics: Digital Activism and Political Change. London: Pluto Press. 